\title{
Relationship Betwen Capital Structure, Profitability and Company Stock Price
}

\author{
Watriningsih $^{1}$, Hapsari Lukaningtyas ${ }^{2}$, H.Hermanto $\mathrm{JM}^{3}$ \\ \{watri_ayu@dsn.moestopo.ac.id ${ }^{1}$, hapsari.1@dsn.moestopo.ac.id ${ }^{2}$,hyginus.h@dsn.moestopo.ac.id ${ }^{3}$ \} \\ ${ }^{1,2,3}$ Universitas Prof.Dr. Moesopo (Beragama), Jalan Hanglekir I Nomor 8 Jakarta, \\ Indonesia
}

\begin{abstract}
The aim of the research is to determine and analyze the relationship between capital structures with stock price. This article focuses on the relationship between profitability with stock price. It is also emphasis the relationship between capital structure, profitability, and stock price. This research is explanatory research. This research explains the causal relationship between the variables through hypothesis. The companies sampled are pharmaceutical companies listed on the Indonesia Stock Exchange in 2001-2012. Data analysis was performed using correlation analysis. The results showed there is negative insignificant relationship between the price of stock and capital structure. It is identified from the relationship value amounted $-0,123$ between the price of stock and DER with $\mathrm{p}_{\text {value }}>\alpha(0,05)$. There is a positive significant relationship between the price of stock and profitability. It is recognized from the correlation value amounted 0,602 between the price of stock and ROA with $p_{\text {value }}<\alpha(0,05)$. There is a positive significant relationship between DER and ROA with the stock price. It is recognized from the correlation value amounted 0,607 between DER and ROA with the stock price with $p_{\text {value }}<\alpha(0,05)$.
\end{abstract}

Keywords: relationship, capital structure, profitability, stock price, pharmaceutical companies

\section{Introduction}

Generally, capital market consideration is limited to stock. It is reflected in the discussion about capital market due to the dominant traded. The discussion of stock is identical to the number of values. [12] states that:" Stock prices are prices stock concerned on the stock exchange at the appropriate time determined by market participants, as well as the demand and supply of the relevant stock in the capital market". This definition reveals the nature of stock price as an indicator of the value of the companies that issues stock in the capital market.

Investors get profits from stock in two sources such as the difference in stock prices (capital gains) and profit sharing (dividend). Investors who expect capital gains are speculators for short-term investors. They buy stock to be immediately resold in case of profitable consideration for them. Investors who expect dividends are long-term investors. They usually retain their stock by hoping that the company's business will advance and make profits. It will be shared with them as shareholders [12].

The stock price is determined by the law of demand and supply or the power of bargaining. If more people want to buy stock, the stock price tends to move up. If more people want to sell stocks, the stock price will move down. The fact shows that there is no stock price continues to rise and fall. The movement of stock prices over a period of time generally forms a certain pattern[1]. 
The movement of stock prices is influenced by economic conditions. Exchange rate is an aspect of economic conditions that greatly affects stock prices. If IDR weakens, the stock price will tend to fall. Stock prices will tend to rise, if IDR exchange rate strengthens. This currency exchange rate is still very influential on the Indonesian capital market because the Indonesian capital market is still dominated by foreign ownership, which is around $66 \%$ of stock hare ownership on the BEI. This condition will affect the stock market being vulnerable to the global financial situation due to the financial capabilities of the owners of the capital. Foreign exchange rates are widely used in the Indonesian capital market such as the US Dollar and the Japanese Yen. It will greatly affect stock prices. The stock price will decline, if the value of the exchange rate rises. Stock prices will increase, if the exchange rate falls [3]

Monetary crisis is another factor that affects stock prices. Monetary crisis usually happen to country that sell their stock to investors and transfer their stock to other fields or to other countries. They usually do that to inexperienced a monetary crisis country. This massive stock sale causes the capital market to weaken, so stock prices usually decline [3].

Stock prices are also influenced by market perceptions of the current condition of the company and the achievements in the future. The current condition of the company which is often used as an indicator of company development is the capital structure. Capital structure is a balance or comparison between the amount of long-term debt and own capital [5]. The optimal capital structure is a balance between the use of own capital and the use of long-term loans. It is the amount of individual capital and long-term debt for optimal operational and corporate profits.

The nature of capital is obtained from the owner of the company by distributing stoke. The advantage of using own capital to finance a business is the absence of interest costs, but it only pays dividends [3]. The use of own capital does not burden the company with interest, but it has a weakness on motivation of company management to achieve optimal results. On the other hand, the source of financing from debt has the disadvantage of having to pay interest and have a greater risk. The advantage of funding source motivates company management to get optimal achievement [3].

There are the company's considerations in choosing funding alternatives to finance company activities. It creates a beneficial combination between the use of sources of funds from equity and funds from long-term debt. These concerns are setting the right composition between long-term debt and equity. Some companies have a capital structure that is not good, for example too much capital comes from debt. It causes a problem to the company.

Another factor that affects stock prices is the achievement they expect in the future. This achievement is company's ability to earn profits (the company's profitability). Profitability in practice is often the main consideration for investors to buy stocks and ignore other aspects.

Listed business sector in Indonesia Stock Exchange is the pharmaceutical sector. Based on transaction data from pharmaceutical companies, it is known that the stock prices of Pharmaceutical Companies in 2001-2012 tend to be less liquid. There are problems affect the price of these stocks. In this regard, it is necessary to conduct research related to the capital structure, profitability and stock prices of pharmaceutical companies. Therefore the topic of this study is relationship between capital structure, profitability and stock price (Study of Pharmaceutical Companies Listed on the Indonesia Stock Exchange 2001- 2012). 


\section{Theoritical Framework \\ 2.1. Stock Price}

The stock price is the price of a stock at a definite time determined by market participants and the demand and supply of the stock in the capital market [12]. Every time the stock price can change, for example in one day at the opening hours of the stock exchange at 9.30 a.m the stock price can change at the closing hours of the stock exchange at 4.00 p.m. It will be different every day, every week, every month, etc. Changes in stock prices are not always positive but it can also be negative due to the number of requests and the number of stock price offers. The stock price movements are fluctuating irregularly but there are also unchanged stock prices due to the absence of demand and supply. These stocks are illiquid because they have little or no volume. So, stock prices are stagnant over time [12].

Stock price movements are random (irregular). It can be analyzed with a fundamental approach. If the report is positive, the stoke price will move positively. The second analysis is a technical approach that is carried out using a chart of stock price movements. If an uptrend occurs, investors will make an investment. If it becomes a downtrend, investors will make sale.

Stock is a sign of the participation ownership of a person or entity in a company. A piece of stock is a piece of paper of ownership (regardless of the portion/amount) of a company that issues paper (stock) of the investment. A stock has value or price.[1] discuss about stock prices categorization such as:Nominal Price, The original price, Market price.

The initial price of the selling price the emission agreement to the investor is the market price of the selling price of an investor to another investor. This price occurs after the stocks are listed on the stock. [4] states three types of stocks such as: Book value, Market value, and Intrinsic value. Stock prices can change. Factors in the influence stock price movements are projections of earnings per stock, received earnings, risk levels from profit projections, proportion of corporate debt to equity, and dividend distribution policies. Other factors in stock price movements are external constraints such as economic activity in general, and the state of the stock market tax [1].

\subsection{Capital Structure}

Target capital structure is a combination of preferred stock debt and equity stock. Companies use it to achieve assets [7]. The opinion explains that the capital structure is a balance or comparison between foreign capital and personal capital. Foreign capital is defined in this case as debt both in the long term and in the short term. Personal capital can be divided into retained earnings and can also be included in the ownership of the company.

\subsection{Profitability}

Profitability is the level success in job. It is an ability to get the target. Profitability has become the central framework to achievement of organizational goals. It is benchmarks to be able to evaluate the plan [2]. [5] states profitability as the ability of a company to earn profits in a certain period of time. It reflects the measurement of company profitability on time. At each of these measurements, an evaluation is carried out on whether the company is able to get good profitability or not.

The success of making profit from the company's business will be a big contribution to the success of the company concerned. Therefore, there is a need for effective business management to eliminate losses. 


\section{Method}

This research method is Explanatory Research. Based on [10] "Explanatory Research", it is used to describe a causal relationship between the variables through testing of hypotheses. This study will be analyzed in the causal relationship of capital structure and profitability with stock prices.

The population in this study was companies in Indonesian Stock Exchange (BEI) list. Sample is a part of the population as subject in experiments [11]. The samples in this study were all pharmaceutical companies listed on the Indonesia Stock Exchange in 2001-2012.

This study consists of three variables such as DER and ROA as independent variables as well as the stock price as the dependent variable. It can be explained with the following illustration:

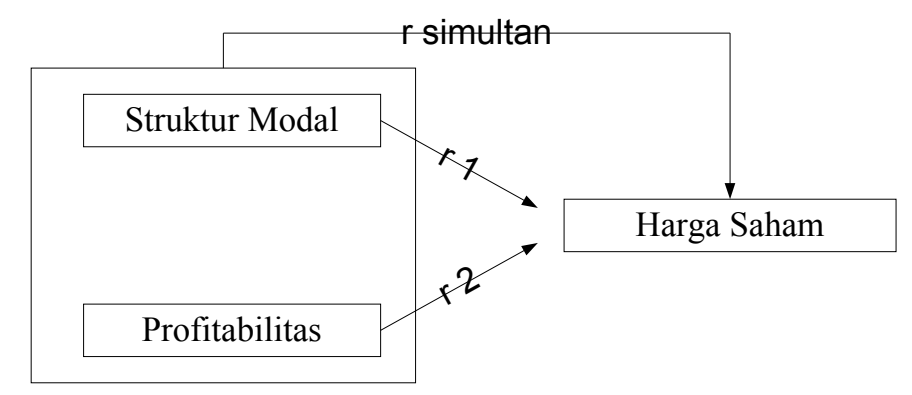

Note:

$\mathrm{r}_{1} \quad:$ the relationship between capital structures partially with the stock price

$\mathrm{r}_{2} \quad:$ the relationship between profitability partially with the stock price

$\mathrm{r}^{\text {simulteneusly: }}$ the relationship between capital structure, profitability and stock prices simultaneously

\section{Results}

\subsection{Data Normality Test}

Normality Test Results of DER, ROA and Stock Price Data

Tests of Normality

\begin{tabular}{ccccccc}
\hline & \multicolumn{3}{c}{ Kolmogorov-Smirnov $^{\mathrm{a}}$} & \multicolumn{3}{c}{ Shapiro-Wilk } \\
DER & Statistic & $\mathrm{df}$ & $\mathrm{Sig}$. & Statistic & $\mathrm{df}$ & Sig. \\
ROA & .309 & 84 & .000 & .546 & 84 & .000 \\
PRICE & .110 & 84 & .014 & .906 & 84 & .000 \\
\hline
\end{tabular}

a. Lilliefors Significance Correction

The test results in normality of data reveal that the requirements are not fulfill for all the variables for the Kolmogorov-Smirnov $<0,05$. 


\subsection{Test of Homogeneity Variance}

From the homogeneity test, it is known that the homogeneity requirements of variance are not fulfilled because the significance value is $<0,05$. The complete test results are in the following table.

Homogeneity Test Results of DER, ROA and Stock Price Data

Test of Homogeneity of Variances

\begin{tabular}{cccc}
\hline PRICE & & & \\
\hline Levene Statistic & df1 & df2 & Sig. \\
8.382 & 21 & 44 & .000 \\
\hline
\end{tabular}

\subsection{Test results}

\subsection{Linear Regression Analysis Simple Effect of DER $\left(X_{1}\right)$ on Stock Prices $(Y)$}

$\mathrm{R}^{2}$ Test Results Effect of DER on Stock Prices

\begin{tabular}{ccrcc}
\multicolumn{2}{c}{ Model Summary } & & & \\
\hline Model & $\mathrm{R}$ & R Square & idjusted R Square & Std. Error of the Estimate \\
1 & $.123 \mathrm{a}$ & .015 & .003 & 19416.96279 \\
\hline \multicolumn{2}{l}{ a. Predictors: (Constant), DER } & &
\end{tabular}

The value of $\mathrm{R}^{2}=0,015(1,5 \%)$. This contribution of DER to the Stock Price is $1.5 \%$ while the remaining amount of: $98.5 \%$ is a contribution from other variables outside of this study.

Anova Test Results Effect of DER on Stock Prices

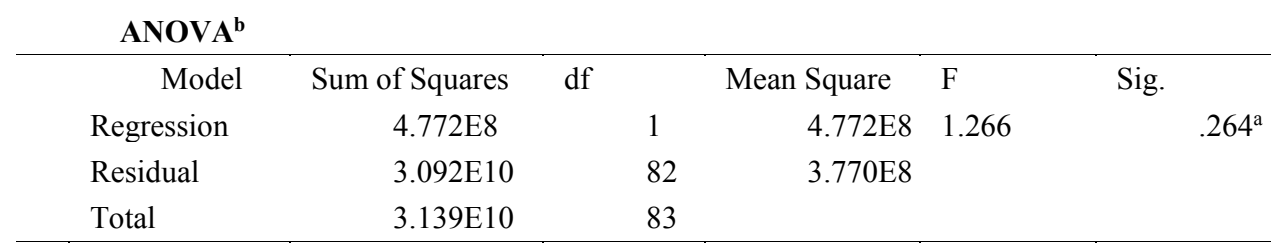

a. Predictors: (Constant), DER

a. Dependent Variable: PRICE

From the table, it is known that $F_{\text {count }}=1,266 . F_{\text {table }}$ with df 1 and 82 means: 3,94 because $\mathrm{F}_{\text {count }}<\mathrm{F}_{\text {table }}$ means a significant regression equation.

Regression Coefficient Effect of DER on Stock Prices

Coefficients

\begin{tabular}{rrrrrr}
\hline \multicolumn{7}{c}{ Unstandardized Coefficients } & \multicolumn{2}{c}{$\begin{array}{c}\text { Standardized } \\
\text { Coefficients }\end{array}$} \\
Model & $\mathrm{B}$ & Std. Error & Beta & $\mathrm{T}$ & Sig. \\
\hline (Constant) & 8485.240 & 3170.142 & & 2.677 & .009 \\
DER & -6375.032 & 5666.348 & -.123 & -1.125 & .264 \\
\hline
\end{tabular}

a. Dependent Variable: PRICE 
This table of coefficients shows the regression equation between DER and Stock Price: Y $=8485,240-6375,032 \mathrm{X}_{1}$. That means the change in one score on DER will result in a change of $-6375,032$ at the Stock Price.

\subsection{Simple Linear Regression Analysis Effect of ROA $\left(\mathrm{X}_{2}\right)$ on Stock Prices $(\mathrm{Y})$}

\begin{tabular}{ccccc}
\multicolumn{5}{c}{ Test Results Effect of ROA on Stock Prices } \\
\hline Model & $\mathrm{R}$ & R Square & Adjusted R Square & Std. Error of the Estimate \\
1 & $.602^{\mathrm{a}}$ & .362 & .354 & 15625.68699 \\
\hline
\end{tabular}

a. Predictors: (Constant), ROA

The value of $\mathrm{R}^{2}=0,362(36,2 \%)$. This means that the contribution of ROA to the Stock Price is $36.2 \%$ while the remaining $63.8 \%$ is a contribution from other variables outside of this study.

Anova Test Results Effect of ROA on Stock Prices

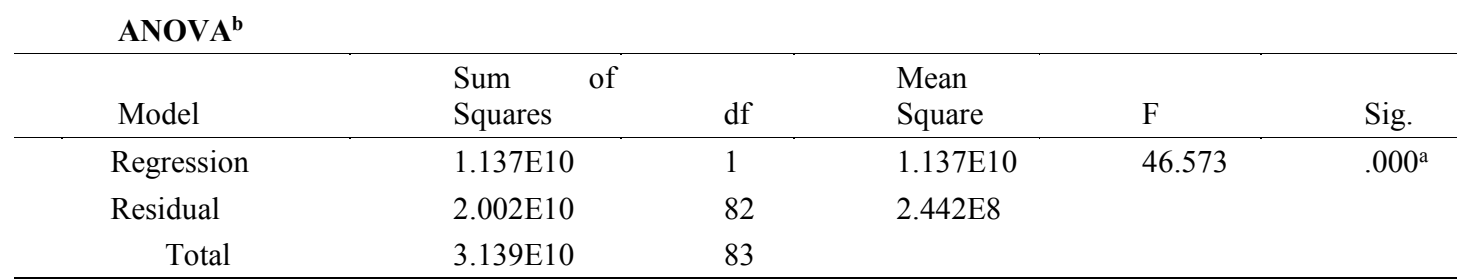

a. Predictors: (Constant), ROA

b. Dependent Variable: Price

From the table, it is known that $F_{\text {count }}=46,573 . F_{\text {table with }}$ df 1 and 82 is 3,94 because $\mathrm{F}_{\text {count }}>\mathrm{F}_{\text {table }}$ means significant regression equation.

\begin{tabular}{|c|c|c|c|c|c|}
\hline \multicolumn{6}{|c|}{ ssion Coefficient Effect of ROA on Stock Prices } \\
\hline \multirow[b]{2}{*}{ Model } & \multicolumn{2}{|c|}{ Unstandardized Coefficients } & \multicolumn{2}{|l|}{$\begin{array}{l}\text { Standardized } \\
\text { Coefficients }\end{array}$} & \multirow[b]{2}{*}{ Sig. } \\
\hline & B & Std. Error & Beta & $\mathrm{t}$ & \\
\hline (Constant) & -10259.405 & 2909.706 & & -3.526 & .001 \\
\hline ROA & 1077.920 & 157.949 & .602 & 6.824 & .000 \\
\hline
\end{tabular}

a. Dependent Variable: PRICE

The coefficient table shows the regression equation between ROA and Stock Price is: $\mathrm{Y}=$ $-10259,405+1077,920 \mathrm{X}_{2}$. This means that a change in one score on ROA will result in a change of 1077,920 at the stock price. 


\subsection{Multiple Linear Regression Analysis Effect of DER $\left(X_{1}\right)$ and ROA $\left(X_{2}\right)$ on Stock}

Prices (Y)

$\mathrm{R}^{2}$ Test Results Effect of DER and ROA on Stock Prices

Model Summary ${ }^{\mathrm{b}}$

\begin{tabular}{cccccc}
\hline Model & $\mathrm{R}$ & $\mathrm{R}$ Square & $\begin{array}{c}\text { Adjusted R } \\
\text { Square }\end{array}$ & $\begin{array}{c}\text { Std. Error of the } \\
\text { Estimate }\end{array}$ & Durbin-Watson \\
\hline 1 & $.607 \mathrm{a}$ & .369 & .353 & 15644.17030 & 1.443 \\
\hline \multicolumn{2}{l}{ a. Predictors: (Constant), ROA, DER } \\
b. Dependent Variable: PRICE
\end{tabular}

The value of $\mathrm{R}^{2}=0,369(36,9 \%)$. It means the contribution of DER and ROA to Stock Prices is $36.9 \%$ while the remaining $63.1 \%$ is a contribution from other variables outside of this study. The standard error of the estimate is 15644,17030 . The value of Durbin - Waston is 1,443 . This value lies between the values of -2 and +2 so that between DER and ROA there is no autocorrelation.

Anova Test Results Effect of DER and ROA on Stock Prices

\begin{tabular}{cccccc} 
ANOVA $^{\mathbf{b}}$ & & & & \\
\hline Model & Sum of Squares & df & Mean Square & F & Sig. \\
\hline Regression & $1.157 \mathrm{E} 10$ & 2 & $5.784 \mathrm{E} 9$ & 23.635 & $.000 \mathrm{a}$ \\
Residual & $1.982 \mathrm{E} 10$ & 81 & $2.447 \mathrm{E} 8$ & & \\
Total & $3.139 \mathrm{E} 10$ & 83 & & & \\
\hline
\end{tabular}

a. Predictors: (Constant), ROA, DER

b. Dependent Variable: PRICE

From this table, it is known that $\mathrm{F}_{\text {count }}=23,635 . \mathrm{F}_{\text {table }}$ with df 2 and 81 are: 3.96 . Because $\mathrm{F}_{\text {count }}>\mathrm{F}_{\text {table }}$ means plural regression equation is significant.

\begin{tabular}{|c|c|c|c|c|c|c|c|c|}
\hline \multicolumn{9}{|c|}{$\begin{array}{r}\text { Reg } \\
\text { Coefficients }^{\mathrm{a}}\end{array}$} \\
\hline & & \multicolumn{2}{|c|}{$\begin{array}{l}\text { Unstandardized } \\
\text { Coefficients }\end{array}$} & \multirow{2}{*}{$\begin{array}{c}\text { Standardized } \\
\text { Coefficients } \\
\text { Beta }\end{array}$} & \multirow[b]{2}{*}{$\mathrm{t}$} & \multirow[b]{2}{*}{ Sig. } & $\begin{array}{l}\text { Collinearity } \\
\text { Statistics }\end{array}$ & \multirow[b]{2}{*}{ VIF } \\
\hline \multicolumn{2}{|c|}{ Model } & B & Std. Error & & & & $\mathrm{e}$ & \\
\hline (Constant) & $\begin{array}{r}\text { (Const } \\
\text { ant) }\end{array}$ & 12805.517 & 4065.213 & & -3.150 & .002 & & \\
\hline \multirow{2}{*}{$\begin{array}{l}\text { DER } \\
\text { ROA }\end{array}$} & DER & 4341.630 & 4834.935 & .084 & .898 & .372 & .892 & 1.122 \\
\hline & ROA & 1127.434 & 167.474 & .630 & 6.732 & .000 & .892 & 1.122 \\
\hline
\end{tabular}

a. Dependent Variable: PRICE

This coefficient table shows the regression equation between DER and ROA with the Stock Price: $\mathrm{Y}=-12805,517+4341,630 \mathrm{X}_{1}+1127,434 \mathrm{X}_{2}$. It means that a change of one score on the DER variable will affect 4341,630 scores on the Stock Price variable. The change of 
one score on the ROA variable will result in a change of 1127,434 scores on the Stock Price variable.

The tolerance values for DER and ROA are 0.892. The VIF values for DER and ROA are 1,122 . There is a way to find out multicollinearity between variables with a view of tolerance value. If the tolerance value is greater than 0.10 , Multicollinearity does not occur to the data tested. Based on of VIF (Variance Inflation Factor), if the value is less than 10.00 VIF it means nothing happens on multicollinearity tested against the data. Based on these criteria, Multicollinearity is not known to occur against the data tested.

Test of Partial Correlation of DER and Stock Price with Controlled ROA

\begin{tabular}{|c|c|c|c|c|}
\hline \multicolumn{5}{|c|}{ Correlations } \\
\hline \multicolumn{3}{|c|}{ Control Variables } & PRICE & DER \\
\hline \multirow[t]{6}{*}{ ROA } & PRICE & Correlation & 1.000 & .099 \\
\hline & & Significance (2-tailed) & . & .372 \\
\hline & & Df & 0 & 81 \\
\hline & DER & Correlation & .099 & 1.000 \\
\hline & & Significance (2-tailed) & .372 & . \\
\hline & & $\mathrm{Df}$ & 81 & 0 \\
\hline
\end{tabular}

The partial correlation of the Stock Price and DER controlled by ROA is 0.099 . This relationship is weak. The relationship between Stock Price and DER controlled by ROA has a significance value of 0.372 . This value is greater than the value of 0.025 . So, the partial correlation is not significant. The value of 0.025 for the results is between 0.05 and 2 , because the significance test is two sides.

Test the Partial Correlation of ROA and Stock Prices with DER Control

\begin{tabular}{|c|c|c|c|c|}
\hline \multicolumn{5}{|c|}{ Correlations } \\
\hline \multicolumn{3}{|c|}{ Control Variables } & PRICE & ROA \\
\hline DER & PRICE & Correlation & 1.000 & .599 \\
\hline & & Significance (2-tailed) & . & .000 \\
\hline & & Df & 0 & 81 \\
\hline & ROA & Correlation & .599 & 1.000 \\
\hline & & Significance (2-tailed) & .000 & . \\
\hline & & Df & 81 & 0 \\
\hline
\end{tabular}

The partial correlation between Stock Price and ROA controlled by DER is 0.599 . This relationship is very strong. The relationship between Stock Price and ROA controlled by DER has a significance value of 0,000 . This value is smaller than the value of 0.025 . So, the partial correlation is significant.

\section{Conclusion}


Based on the analysis and discussion, there are conclusions such as:

There is a negative, insignificant relationship between Stock Prices and Capital Structure. It is reflected on the results of correlation between stock price and DER of $-0,123$ with $p_{\text {value }}>$ $\alpha(0,05)$. The meaning of this negative relationship is that if the DER increases, the stock price decreases. Otherwise, if DER decreases, the stock price increases. The existence of this negative relationship shows in some cases. If DER values are higher, the risk of default on a company is getting higher. On the other hand, the greater of DER will effect on the more possible of less company's expansion opportunities. This condition is not beneficial for the investors. The investors will sell the company's stock on this case. The more stock are sold, the price is lower.

There is a significant positive relationship between stock prices and profitability. It is reflected on the results of the correlation test which obtained a correlation value between Stock Price and ROA of 0,602 with $p_{\text {value }}<\alpha(0,05)$. The meaning of this positive relationship is if the ROA increases, the stock price increases. Similarly, if ROA decreases, the stock price decreases. The existence of a positive relationship is due to the greater the ROA. It creates the better of the company's performance because the level of return increases. This situation is preferred by investors. They make purchases of company stock. If more people want to buy company stock, the price of the stock will be higher.

There is a significant positive relationship between DER and ROA with Stock Prices. It is reflected from the results of the correlation test which obtained a correlation value between Stock Prices and ROA of 0,607 with $p_{\text {value }}<\alpha(0,05)$. The existence of a significant relationship between stock prices with DER and ROA indicates that these two variables are indeed very strongly related to stock prices. DER is usually a variable that is used as a reference by investors to avoid buying the stock in question, whereas ROA is used by investors to be a guide to buying stock. Furthermore, investors will compare the DER value with ROA. If the value of ROA is greater than DER, investors will decide to buy stock.

\section{Reference}

[1]. Darmadji, T. and Fakhruddin, H.M. (2011). Capital market in Indonesia. Pasar modal di Indonesia. 3rd edition. Jakarta: Salemba Empat.

[2]. Fahmi, I. (2010). Management of theory and application performance. Manajemen kinerja teori dan aplikasi. Bandung: Alfabeta.

[3]. Gitosudarmo, I. (2002). Financial management. Managemen keuangan. 4rd edition. Yogyakarta: BPFE.

[4]. Hartono, J. (2011). Portfolio theory and investment analysis. Teori portofolio dan analisis investasi. Yogyakarta: BPFE.

[5]. Husnan, S. and Pujiastuti, E. (2004). Fundamentals of financial management. Dasardasar manajemen keuangan. Jilid 4. Yogyakarta: UPP AMP YKPN.

[6]. Husnan, S. and Pujiastuti, E. (2008). Basics of portfolio theory and securities analysis. Dasar-dasar teori portofolio dan analisis sekuritas. Yogyakarta: UPP AMP YKPN.

[7]. Prasetyo, H. (2010). Guide to investing in the capital market. Panduan investasi di pasar modal. Jakarta: Salemba Empat.

[8]. Riyanto, B. (2011). Basics of company spending. Dasar-dasar pembelanjaan perusahaan. Yogyakarta: Yayasan Badan Penerbit UGM.

[9]. Santoso, S. (2010). SPSS Parametric Statistics Exercise Book. Buku Latihan SPSS Statistik Parametrik. Jakarta: Elex Media Komputindo. 
[10]. Singarimbun, M. \& Effendi, S. (Editor). (2008). Survey research method. Metode penelitian survey. Jakarta: PT Pustaka LP3ES.

[11]. Sugiyono. (2010). Administration research method. Metode penelitian administrasi. Bandung: CV Alfabeta.

[12]. Sunariyah. (2011). Introduction to capital market knowledge. Pengantar pengetahuan pasar modal. 6th Edition. Yogyakarta: Sekolah Tinggi Ilmu Manajemen YKPN. 